\title{
Effects of ENSO on the major ion record of a Qomolangma (Mount Everest) ice core
}

\author{
Hao XU, ${ }^{1,2}$ Shugui HOU, ${ }^{1}$ Hongxi PANG, ${ }^{1}$ Chaomin WANG ${ }^{1}$ \\ ${ }^{1}$ MOE Key Laboratory for Coast and Island Development, School of Geographic and Oceanographic Sciences, \\ Nanjing University, Nanjing, China \\ ${ }^{2}$ Institute of Desertification Control, Ningxia Academy of Agriculture and Forestry Science, Yinchuan, China \\ Correspondence: Shugui Hou <shugui@nju.edu.cn>
}

\begin{abstract}
Correlations between a 1000 year record of the major ions in a $108.83 \mathrm{~m}$ ice core from East Rongbuk Glacier $\left(2^{\circ} 01^{\prime} \mathrm{N}, 86^{\circ} 58^{\prime} \mathrm{E}\right.$; $6518 \mathrm{~m}$ a.s.l.) on the northeast slope of Qomolangma (Mount Everest) and the Southern Oscillation Index (SOI) were examined to investigate possible links between the ice-core records of the southern Tibetan Plateau (TP) and El Niño Southern Oscillation (ENSO). The results show that years with the highest crustal ion concentrations and lowest marine ion concentrations corresponded with a low SOI, and vice versa. Cross wavelet and wavelet coherence analysis between major ion time series and the SOI indicated that there were significant sections with high common power between the major ion time series and the SOI, suggesting a correlation between the ion records of the Qomolangma ice core and ENSO. Further investigation indicated that the higher SOI years corresponded with weaker continental air masses and stronger south Asian monsoons over the southern TP, leading to increased marine ions and decreased continental ions transported to the southern TP. The in-phase surface pressure anomalies of the southern TP and Darwin, Australia, link ENSO and ion transport over the southern TP, and thus suggest a link between aerosol transport over the southern TP and ENSO.
\end{abstract}

KEYWORDS: ice core, paleoclimate

\section{INTRODUCTION}

Ice cores drilled from carefully selected sites are often used to provide palaeoenvironmental records with seasonal, annual, decadal and centennial resolutions (Thompson and others, 2000). The Tibetan Plateau (TP) is the highest plateau in the world, with a vast number of mountain glaciers. Ice cores from TP glaciers preserve a wealth of high-resolution climatic information for the mid-latitudes and even the Northern Hemisphere (Mayewski and others, 1984; Thompson and others, 2000). Studies of the major ions in ice cores recovered from the southern TP have shown that ion concentrations are influenced by atmospheric circulation over this region (Kang and others, 2002; Kaspari and others, 2007). Ions transported to the southern TP come from two main sources: marine aerosols from the Arabian Sea and the Bay of Bengal, and crustal aerosols from central and southern Asia. Several ions $\left(\mathrm{Ca}^{2+}, \mathrm{Mg}^{2+}\right.$, $\mathrm{SO}_{4}{ }^{2-}$ and $\mathrm{NO}_{3}{ }^{-}$) show higher concentrations during the non-monsoon season, when dust aerosols are brought in from the arid regions of central and southern Asia. The aforementioned ions are associated with the predominance of continental air masses (Wake and others, 1993; Kang and others, 2002). Marine ions are transported to the southern TP during the summer, and have been associated with the occurrence of the south Asian monsoon (Wake and others, 1993; Shrestha and others, 2002). The ice-core record of the southern TP has also been related to several climatic modes, such as the North Atlantic Oscillation, Pacific Decadal Oscillation and Asian-Pacific Oscillation (Wang and others, 2002; Grigholm and others, 2009; Xu and others, 2014). Therefore, the ice-core records of TP glaciers provide a unique opportunity to uncover the history of the climatic modes on a millennial timescale.
The El Niño Southern Oscillation (ENSO) phenomenon, which occurs in the tropical Pacific, is the strongest internal climate mode on an interannual timescale. It cycles over a 2-7 year period. The warm and cold phases of ENSO are known as El Niño and La Niña, respectively. The ENSO phenomenon is not only a direct result of climate anomalies in the tropical Pacific, but also represents the leading mode of interannual climate variability globally (Mokhov and Smirnov, 2006). ENSO signals are often found in ice-core records (Thompson and others, 2000; Yang and others, 2000; Knüsel and others, 2005). For example, Yang and others (2000) found that fewer precipitation anomalies of the TP are significantly associated with El Niño years but poorly associated with the negative anomaly trend of $\delta^{18} \mathrm{O}$ of the Guliya ice-core record. Wang and others (2003) suggested that the $\delta^{18} \mathrm{O}$ time series of the Malan ice core is related to Southern Oscillation indices, possibly driven by the influence of ENSO on the temperature of the TP, via the strength of westerlies and the Indian monsoon. Although possible relationships between the $\delta^{18} \mathrm{O}$ records from the TP ice core and ENSO have been studied, less is known about the effects of ENSO on the ion records of TP ice cores and the associated mechanisms.

\section{DATA AND METHODS}

In 2002, a $108.83 \mathrm{~m}$ ice core was recovered from the col of East Rongbuk Glacier, located on the northeast ridge of Qomolangma (Mount Everest) in the central Himalaya $\left(27^{\circ} 59^{\prime} \mathrm{N}, 86^{\circ} 55^{\prime} \mathrm{E} ; 6518 \mathrm{ma.s.l}\right.$.) (Fig. 1). The ice core was maintained at $<-5^{\circ} \mathrm{C}$ and shipped frozen to the University of Maine, Orono, ME, USA, for processing and analyses. It was melted into discrete samples at $3-4 \mathrm{~cm}$ 


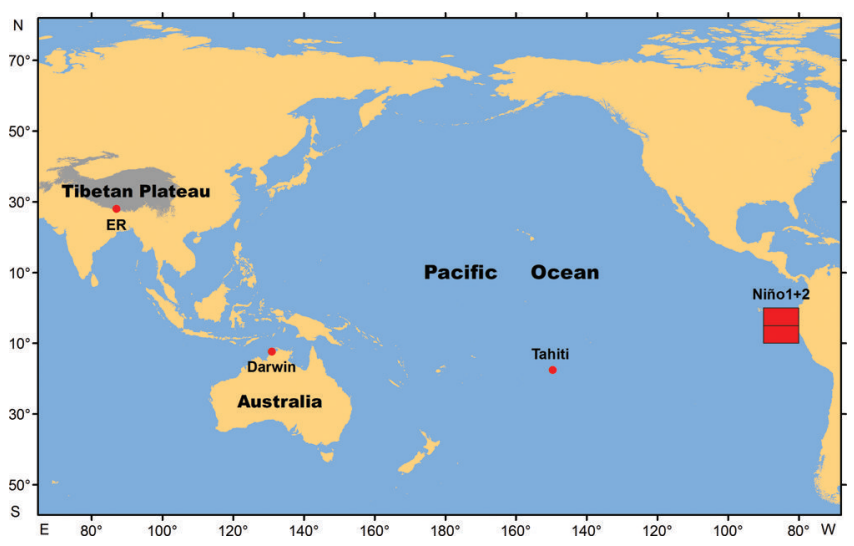

Fig. 1. Location map of East Rongbuk Glacier and Darwin (red dots), Tibetan Plateau (grey shaded area) and Niño 1+2 region (red shaded area).

resolution using an aluminium melter head with the University of Maine's continuous melter system. The melter head splits the meltwater into two different channels: meltwater from the outer portion of the ice core is collected in an outer channel for isotope analyses, and meltwater from the innermost section of the ice core is collected in an inner channel for major ion and trace element analyses (Kaspari and others, 2009). Osterberg and others (2006) provide detailed information on the melter system. The concentration of major soluble ions was analyzed by a Dionex chromatograph (DX-500). The ice core was dated to AD 1534 at a depth of $98 \mathrm{~m}$ based on seasonal variations in $\delta \mathrm{D}$ and soluble ions. Below $98 \mathrm{~m}$, it was dated by a flow model (Kaspari and others, 2007, 2008). The dating error was \pm 0 years at AD 1963 and \pm 5 years at AD 1534 (Xu and others, 2010). More dating information is given in Kaspari and others $(2007,2008)$. The date at the bottom was estimated as 1650 years BP (Hou and others, 2004). In this study the section of core spanning AD 1003-2002 was used.

The Southern Oscillation Index (SOI) is defined as the normalized pressure difference between Tahiti and Darwin, Australia. In this study, we use the SOI calculated based on the method given by Ropelewski and Jones (1987) (Allan and others, 1991; Können and others, 1998).

Empirical orthogonal function (EOF) analysis of the major ions of ice cores reveals their common variance and the relationships between the major ions, and also yields new time series representing their relationships (Meeker and others, 1995; Kang and others, 2002; Meeker and Mayewski, 2002). EOF analysis was conducted on the annual average concentrations of major ions covering AD 10032001. Figure 2 presents the EOF time series and major ions of the ice core over the past 1000 years.

Wavelet analysis is a useful mathematical technique for analyzing time signals of time-varying magnitudes and periodicities. Wavelet transforms expand time series into time-frequency space and can therefore find localized intermittent periodicities. The continuous wavelet transform (CWT) is a common tool for analyzing localized intermittent oscillations in a time series, when it is often desirable to examine together two time series that may be linked. In particular, it is useful for examining whether regions in timefrequency space with large common power have consistent phase relationships and are therefore suggestive of causality between the time series (Grinsted and others, 2004). Based
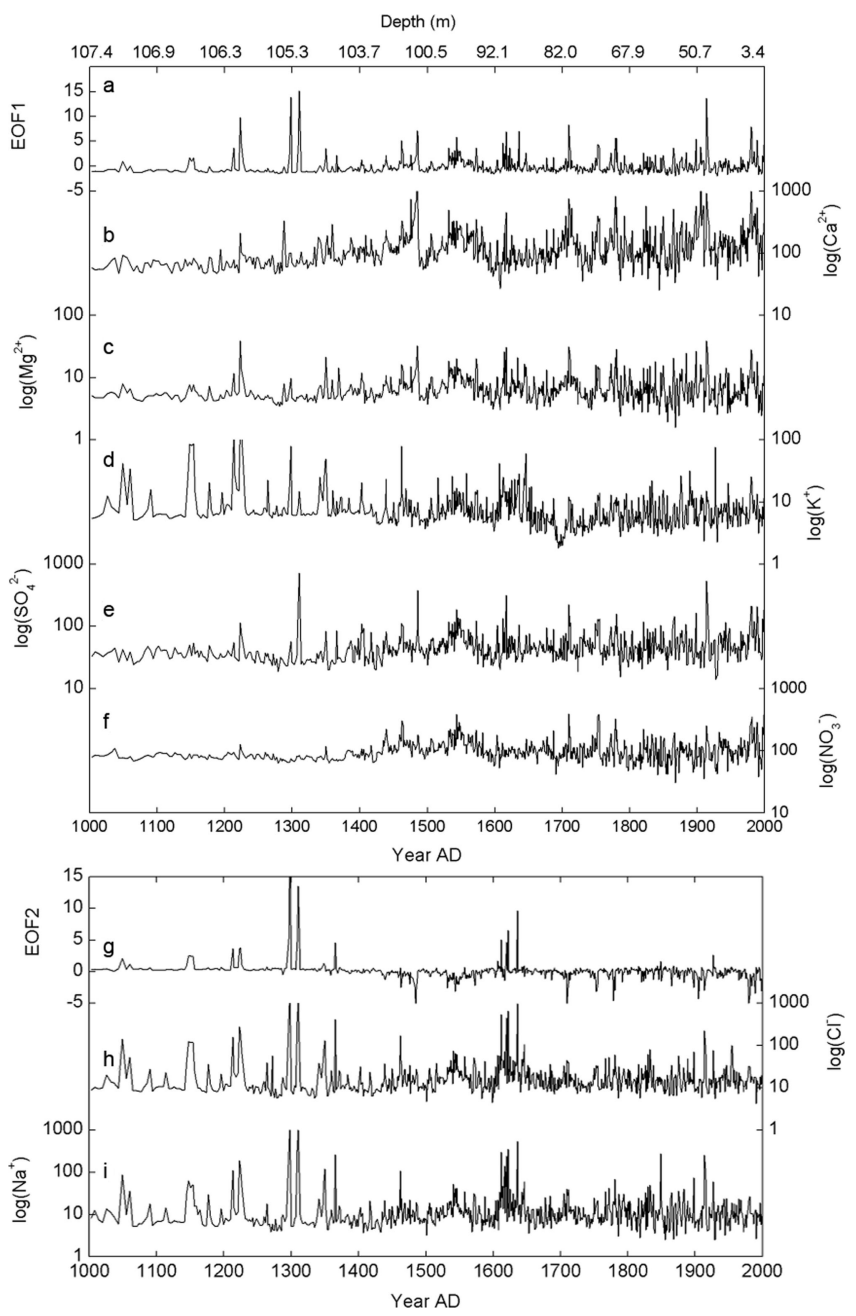

Fig. 2. Variation of the major ions $\left(\mu \mathrm{g} \mathrm{L}^{-1}\right)$ of the East Rongbuk ice core. (a-f) Time series of EOF1 and crustal major ions; (g-i) time series of EOF2 and marine major ions.

on CWT, the cross wavelet transform (XWT) will expose their common power and relative phase in time-frequency space. Wavelet coherence (WTC) can find significant coherence, even when the common power is low (Grinsted and others, 2004). In this study, the cross wavelet power was calculated to estimate the covariance between SOI and EOF time series, and wavelet coherence was calculated to measure the cross correlation between the two time series as a function of frequency.

\section{RESULTS AND DISCUSSION \\ Comparison of major ion record and SOI}

EOF analysis of the major ions revealed common variations of these ions over the past millennium. EOF1 accounts for $43.8 \%$ of the total variance in the major ion time series, with $\mathrm{Mg}^{2+}, \mathrm{Ca}^{2+}, \mathrm{NO}_{3}{ }^{-}$and $\mathrm{SO}_{4}{ }^{2-}$ strongly loaded on EOF1. The high common variance suggests a common source or transport pathway for these ions, with dust from the arid regions of central Asia being the dominant source (Kang and others, 2002). These ions are derived from the mineral aerosols of the central Asia arid zone and controlled by continental air masses (Wake and others, 1990, 1993; Kang and others, 2002; Kaspari and others, 2007). EOF2 accounts for $27.9 \%$ of the total variance in the major ion time series, with $\mathrm{Cl}^{-}$and $\mathrm{Na}^{+}$highly loaded on EOF2. Most of the $\mathrm{Na}^{+}$ 

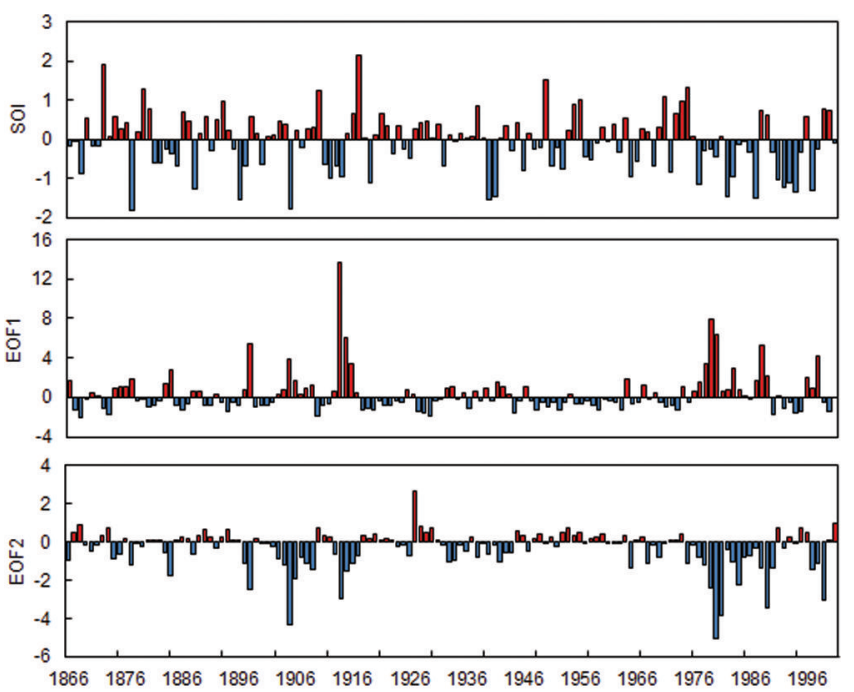

Year $A D$

Fig. 3. SOI and EOF time series over 1866-2001.

and $\mathrm{Cl}^{-}$is transported inland during the monsoon season and is associated with marine air masses from the Bay of Bengal and the Arabian Sea (Shrestha and others, 2002; Kaspari and others, 2007). EOF3 (12.5\% of the total variance) accounts for $81.8 \%$ of $\mathrm{K}^{+}$, representing a unique origin for $\mathrm{K}^{+}$. Although the source of $\mathrm{K}^{+}$cannot be determined, a possible source may be local or regional (north or south of the Himalaya) mineral aerosols (Kang and others, 2002). Here we focus on the EOF1 and EOF2 time series, which represent the continental and marine major ion time series, respectively.

Figure 3 reveals variations in the EOF time series and SOI during the past 136 years (the overlapping period is AD 1866-2001). A comparison between the EOF and SOI time series showed that the high EOF1 corresponded with a low SOI, and the high EOF2 corresponded with a high SOI. Correlation analysis (conducted after a 5 year running mean smoothing filter was applied to both) indicated that the EOF1 time series was negatively correlated with the SOI $(n=136, r=-0.317, p<0.01)$ and the EOF2 time series was positively correlated with the SOI $(n=136, r=0.374$, $p<0.01$ ).

The CWTs of the SOI and EOF time series are shown in Figure 4 . The SOI had high power in the 2-7 year band of the whole period, although for some periods the power was not above the $5 \%$ significance level. There were obvious common features in the wavelet power of the two time series, such as significant peaks in the 8-12 year band between 1900 and 1920, and the $\sim 4$ year and $\sim 8$ year band between 1978 and 1990. However, differences and similarities between the three time series were hard to identify, and thus XWT and wavelet coherence helped in this regard.

The XWT of the SOI and EOF1 is shown in Figure $5 \mathrm{a}$. There was significant common power in the $\sim 6-12$ year band between 1900 and 1920, and the SOI lagged the EOF1 by a quarter of a year in the 3-6 year band between 1978 and 1990, during which period the SOI and EOF1 were in phase. In the most high-power region, an anti-phase relationship existed, although for some periods the power was not above the $5 \%$ significance level. The squared WTC of the SOI and EOF1 is shown in Figure 5b. Compared with the XWT, a larger significant section was found and overall there was an anti-phase relationship between EOF1 and the SOI.
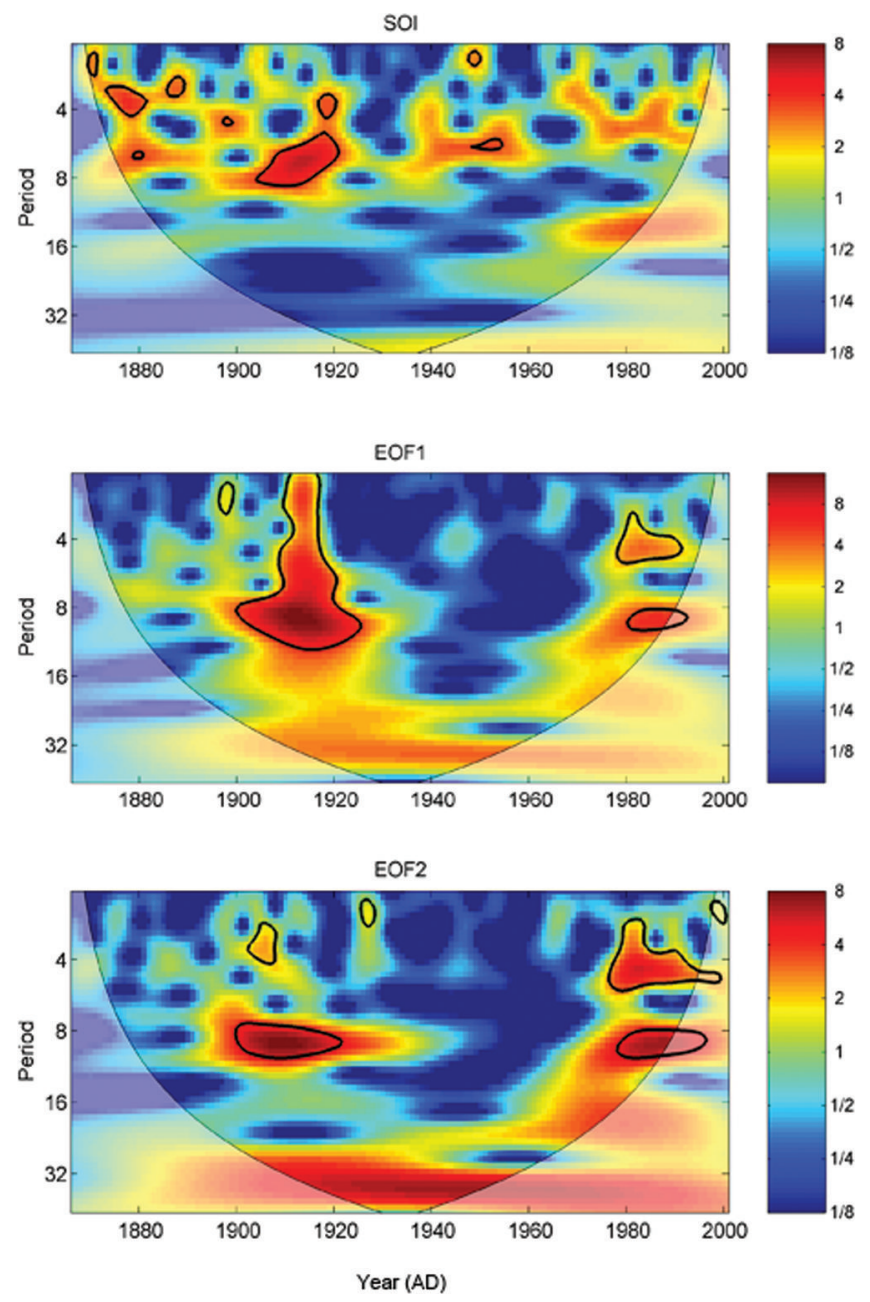

Fig. 4. Continuous wavelet power spectra of SOI index and EOF time series. Thick black contour designates the $5 \%$ significance level against red noise; the cone of influence where edge effects might distort the picture is shown as a lighter shade.

The XWT analysis and squared WTC between the SOI and EOF2 are shown in Figure $5 \mathrm{c}$ and $\mathrm{d}$. The $\sim 6-12$ year band between 1900 and 1920 and the $\sim 3-6$ year band between 1978 and 1990, with in-phase and anti-phase relationships respectively, are noticeable in Figure 5c. The generally in-phase relationship between the two time series existed in the high-power region (including the area below the $5 \%$ significance level). Grinsted and others (2004) reported that, although the area of a time-frequency plot above the $5 \%$ significance level is not a reliable indication of causality, it is possible for two series to be perfectly correlated at one specific scale, while the area of significant correlation is much less than $5 \%$. Although the phases of the $\mathrm{SOI}$ and EOF time series in different periods and bands were different, a relationship existed between the two time series in specific periods. We therefore speculate that there is a link between the major ion record of the Qomolangma ice core and ENSO.

\section{Mechanisms}

Qomolangma lies at the boundary between continental air masses associated with the westerlies and marine air masses associated with the south Asian summer monsoons (Kaspari and others, 2007). Continental ions over the southern TP are closely related to the strength of continental air masses. In 

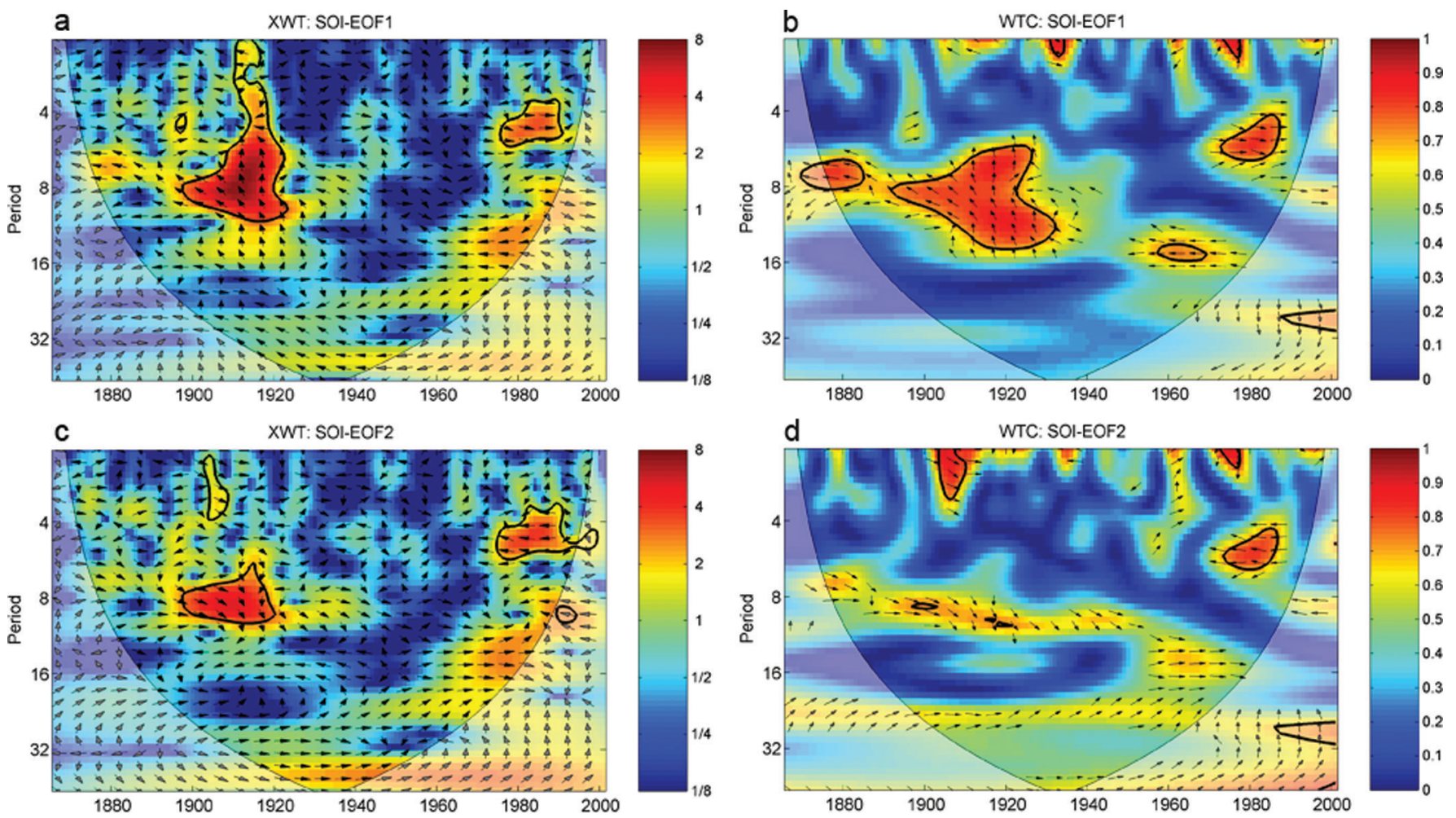

Fig. 5. Cross wavelet transform and squared wavelet coherence of the SOI and EOF time series. (a, c) Cross wavelet transform of SOI with EOF1 and EOF2 time series, respectively. (b, d) Squared wavelet coherence of SOI with EOF1and EOF2 time series, respectively. Thick black contour indicates the $5 \%$ significance level against red noise. Arrows suggest the relative phase relationship, with those in phase pointing right and those not in phase pointing left; arrows pointing vertically upward indicate that the SOI lags the EOF time series by $90^{\circ}$; arrows pointing vertically downward indicate that the SOI leads the EOF time series by $90^{\circ}$.

the winter, stronger westerlies transport more continental species to the southern TP (Kang and others, 2002); in the summer, stronger continental air masses over the southern TP (anomalously high surface pressure over Asia, with the centre located around Mongolia) are related to high concentrations of continental ions in the ice core (Kaspari and others, 2007). Marine ions over the southern TP are transported by the south Asian summer monsoons (Kang and others, 2002; Kaspari and others, 2007). When the summer surface pressure on the Asian continent is lower (the centre region is also around Mongolia), the south Asian monsoon over the southern TP will move further northward, resulting in strengthened south Asian monsoons over Qomolangma and weakened continental air masses (Kaspari and others, 2007). In this situation, more marine ions will be transported to the southern TP, while at the same time the concentration of continental ions decreases (Kaspari and others, 2007). Therefore, the surface pressure of the Asian continent is an indicator of the strength of continental air masses and south Asian monsoons.

To investigate possible mechanisms for the linkage between ENSO and the transport of aerosols to the ice-core site, we examined the sea-level pressure (SLP) anomalies of the highest $(\geq a+\delta$, where $a$ and $\delta$ are mean and standard deviation, respectively) and lowest $(\leq a-\delta)$ years of the EOF time series and the SOI. Investigations of SLP anomalies found that during the highest (lowest) EOF1 years, the annual surface pressure of the Asian continent and the region around Australia were anomalously high (low). At the same time, the surface pressure of the eastern tropical Pacific Ocean was anomalously low (high) (Fig. 6a), with an inverse situation in the pressure anomaly in the highest (lowest) SOI years (Fig. 6c). In contrast, during the highest (lowest) EOF2 years, the summer surface pressure of the Asian continent and the region around Australia was anomalously low (high), and the surface pressure of the eastern tropical Pacific Ocean was anomalously high (low) (Fig. 6b), with a similar situation in the summer pressure anomaly in the highest (lowest) SOI years (Fig. 6d). During the anomalously low SOI years, the surface pressure around Australia and most regions of the Asian continent was high; over the southern TP, the continental air masses strengthened and marine air masses weakened. This situation is advantageous for the transport of more crustal aerosol to the southern TP (Kang and others, 2002; Kaspari and others, 2007). In contrast, during the anomalously high SOI years, the surface pressure around Australia and most regions of the Asian continent was low, the control of continental air masses weakened and the impact of the south Asian monsoon strengthened, which benefited marine ion transport to the southern TP.

These patterns indicate that the in-phase surface pressure anomaly of the Asian continent and Australia is linked to the ENSO and ions transported over the southern TP. Thus, the SLP of the southern TP and Darwin $\left(12.33^{\circ} \mathrm{N}, 130.98^{\circ} \mathrm{E}\right)$ were also investigated. Figure 7 shows similarities in the annual SLP (US National Centers for Environmental Prediction/US National Center for Atmospheric Research (NCEP/ $\mathrm{NCAR}$ ) re-analysis data; $27-32^{\circ} \mathrm{N}, 80-95^{\circ} \mathrm{E}$ ) fluctuation of the southern TP and Darwin (instrumental data: www.cru. uea.ac.uk/cru/data/soi/). In only two of the series, EOF analysis resulted in a decomposition in which the first EOF component expressed the dominant similarity (positive correlation) or dissimilarity (negative correlation) between the two series and estimated the common forcing series 
a

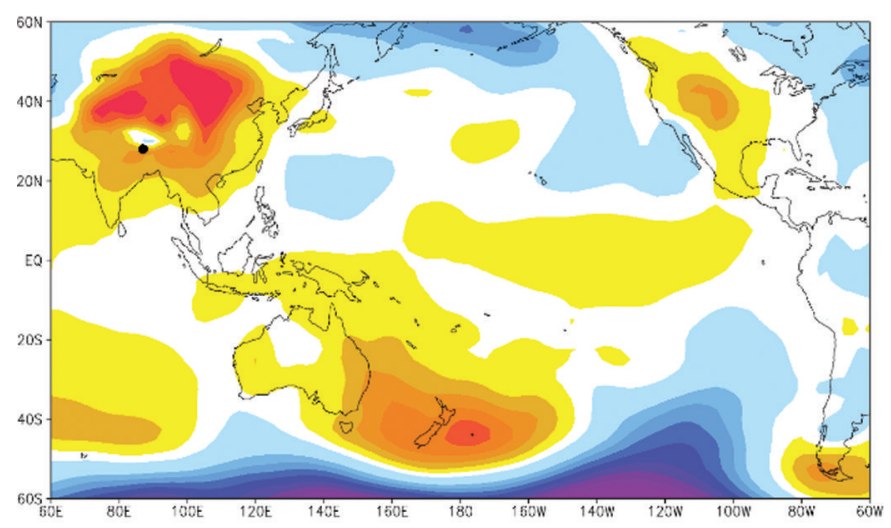

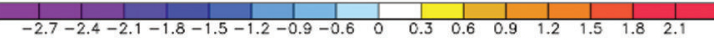

C

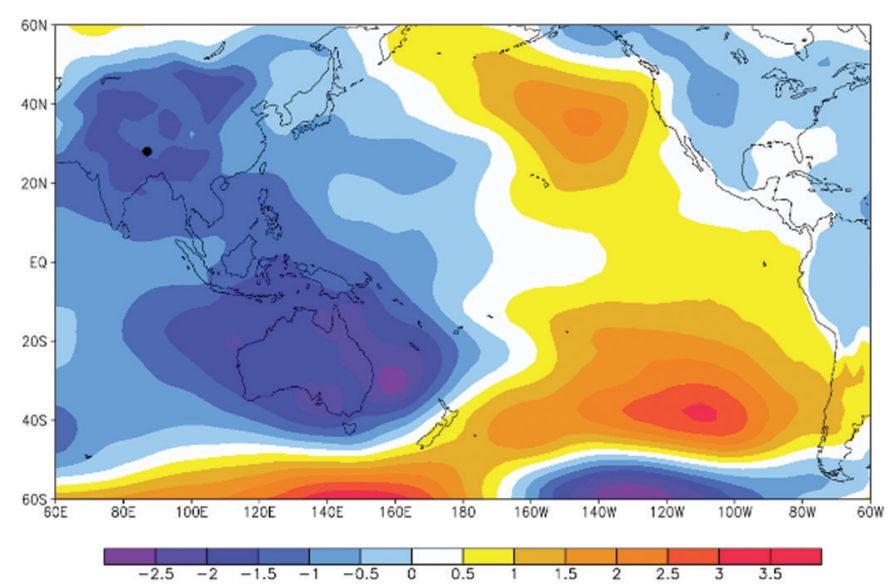

b

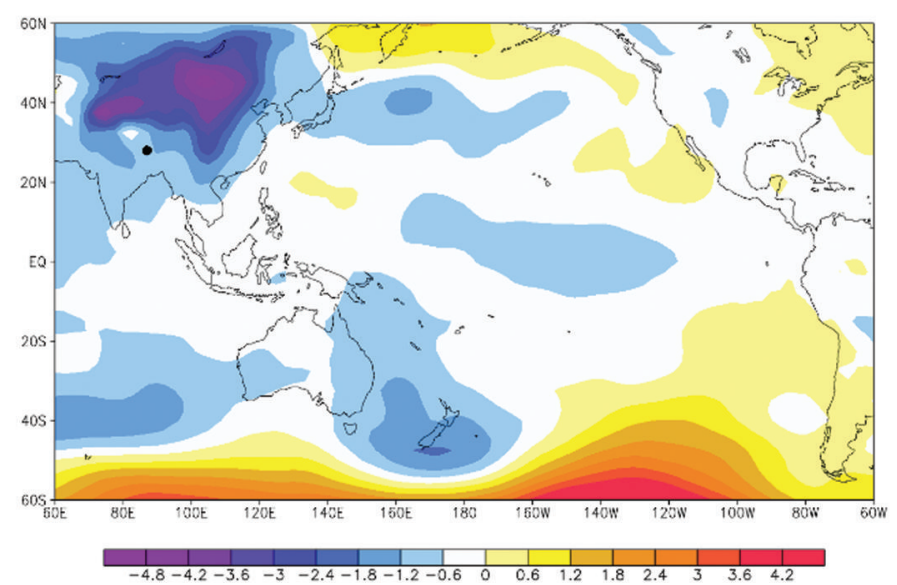

d

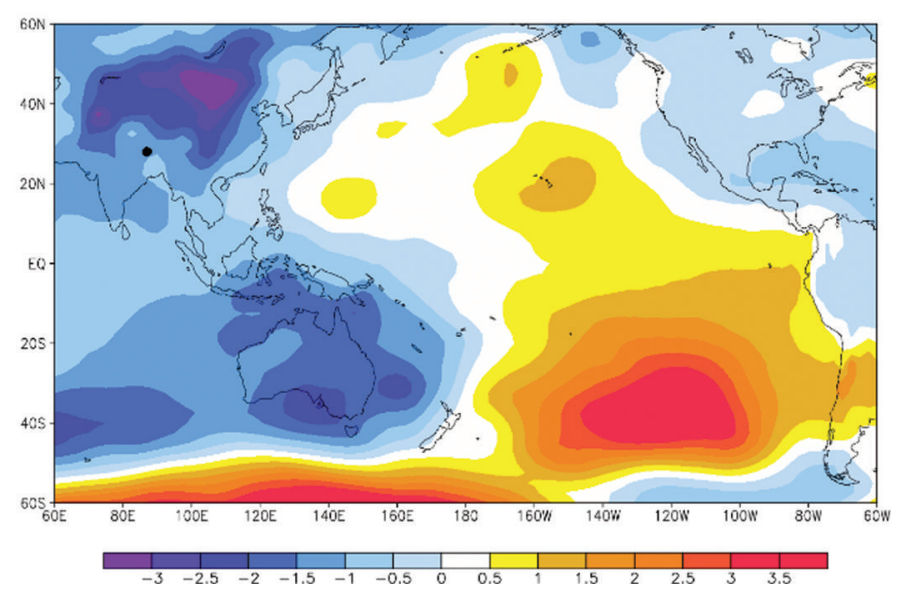

Fig. 6. Annual and summer pressure anomalies around the TP and Pacific Ocean. (a) Annual SLP composite differences of high/low years of EOF1; (b) summer SLP composite differences of high/low years of EOF2; (c) annual SLP composite differences of high/low years of SOI; (d) summer SLP composite differences of high/low years of SOI. Black dot indicates East Rongbuk Glacier.

(Meeker and Mayewski, 2002). Therefore, EOF analysis was conducted on the annual SLP of the southern TP and Darwin, revealing that $76 \%$ of the variance in the SLP in these regions is represented by their common first EOF. This indicated that, on an annual timescale, the SLP of Darwin and the southern TP have similar in-phase variances in the anomalous high and low SOI years. The correlation
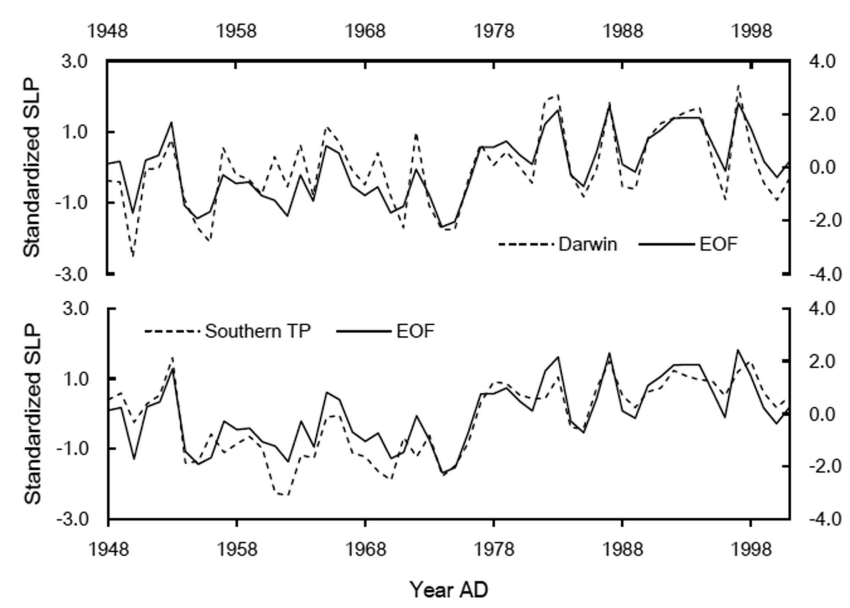

Fig. 7. Annual SLP of the southern TP and Darwin over 1948-2002. EOF analysis on SLP time series of southern TP and Darwin shows that they share $76 \%$ of common variance. between the Southern Oscillation and the ice record of the southern TP is thus linked via in-phase anomalous pressure.

Previous studies found less precipitation and decreased temperatures of the TP are associated with El Niño years (Yang and others, 2000; Zhang and others, 2000). Thompson and others (2000) reported that high levels of dust in the southern TP are concurrent with very strong ENSO events. Records of Malan ice cores of the TP also indicated that the temperature of the northern TP was positively correlated with SOI (Wang and others, 2003). Further, a study of the Dunde ice core showed that the accumulation was positively correlated with the SOI (Davis and others, 2005). These findings suggest that during the warm phase of ENSO (EI Niño), the pressure above Asia increases; lower temperature, decreased precipitation and increased dust will be prevalent over the TP, and the south Asian monsoon weakens over the southern TP. During the cool phase of ENSO (La Niña), the pressure above Asia decreases; higher temperature, increased precipitation and decreased dust become prevalent over the TP, and the south Asian monsoon strengthens over the southern TP.

\section{Comparison with other ENSO indices on millennial timescale}

To investigate the relationship of the East Rongbuk ice-core record and ENSO on a millennial timescale, we compared the EOF time series and six other reconstructed ENSO 

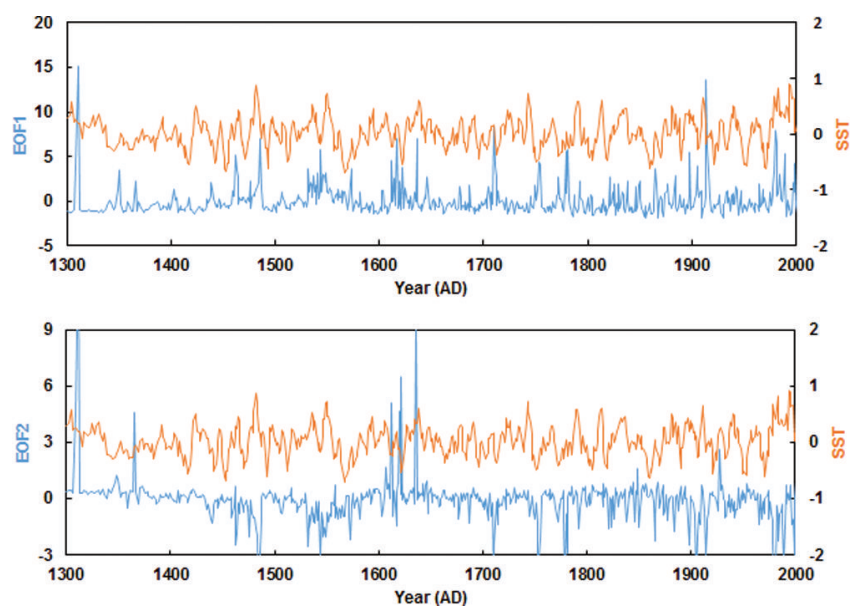

Fig. 8. Comparison of EOF time series and SST of Niño 1+2 (Cook and others, 2008). The period of overlap is 1300-2000.

indices (D'Arrigo and others, 2005; Fowler and others, 2008; Braganza and others, 2009; McGregor and others, 2010; Li and others, 2011, 2013). The results showed that the EOF1 time series was weakly correlated or not correlated with the ENSO indices. When compared with the reconstructed tropical Pacific sea surface temperature (SST) (Cook and others, 2008), we found a similar fluctuation between the EOF time series and tropical Pacific SST, especially the SST of the Niño $1+2$ region (Fig. 8). Correlation analysis showed that EOF1 was positively correlated with the SST of Niño $1+2(r=0.25, p<0.1)$ and EOF2 was negatively correlated with the SST of Niño $1+2(r=-0.13$, $p<0.1)$. This indicates that an inverse relationship existed between the surface temperature anomalies of the southern TP and the eastern tropical Pacific (similar to Fig. 6).

Most of the millennial ENSO indices mentioned above are reconstructed via tree-ring records from North America, South America, Australia and New Zealand, which represent records from the eastern and southern margins of the Pacific, and thus partially recorded the ENSO signals. The East Rongbuk ice core is located in the Northern Hemisphere near the west Pacific Ocean, so it is reasonable that the ice-core record was weakly correlated with other reconstructed ENSO indices. However, the correlation between the ice-core record and Darwin SLP and Niño $1+2$ SST indicates that the major ion records of the southern TP could capture ENSO signals, and thus the ice-core records of the southern TP have the potential for future multi-proxy ENSO reconstruction.

\section{CONCLUSIONS}

EOF analysis of the major ion time series was performed to investigate inter-species relationships and their common variances in a $108.83 \mathrm{~m}$ Qomolangma ice core. EOF analysis indicated that most of the major ions $\mathrm{Mg}^{2+}, \mathrm{Ca}^{2+}$, $\mathrm{NO}_{3}{ }^{-}$and $\mathrm{SO}_{4}{ }^{2+}$ ) were strongly loaded on EOF1, and $\mathrm{Cl}^{-}$ and $\mathrm{Na}^{+}$were highly loaded on EOF2. We analyzed the correlation between EOF time series and the SOI, and found that the SOI was negatively correlated with EOF1 and positively correlated with EOF2. This was linked to the association of continental ions and marine ions with continental air masses and south Asian monsoons, respectively. The cross wavelet and wavelet coherence analysis between EOF time series and SOI found some significant sections with high common power, showing an anti-phase relationship between EOF1 and SOI and in-phase relationship between EOF2 and SOI. This indicates that a relationship existed between the ion record and the SOI in specific periods. Therefore, we suggest that ENSO is associated with air mass activities over the TP.

Investigations of surface pressure found an in-phase variation of the southern TP and Australia, and anti-phase variation of the southern TP and eastern tropical Pacific. These results indicate that during the warm phase of ENSO the surface pressure of the TP is higher, and the continental air mass over the southern TP is stronger and carries more continental ions to the southern TP. During the cold phase of ENSO, the surface pressure of the TP is lower, and the south Asian monsoon over the southern TP is stronger and carries more marine ions to the southern TP. We concluded that ENSO, as a global climatic pattern, could influence the ion record of the TP ice cores.

In the Northern Hemisphere, the TP ice core is an important asset for exploring the history of ENSOs. Furthermore, the ice-core record of the TP is an important supplementary proxy for multi-proxy ENSO reconstruction.

\section{ACKNOWLEDGEMENTS}

We thank many scientists, technicians, graduates and porters for their hard work in the field. This work was supported by the Natural Science Foundation of China (41330526, 41171052 and 41321062), the Chinese Academy of Sciences (XDB03030101-4) and the Priority Academic Program Development of Jiangsu Higher Education Institutions. We thank our scientific editor, Shichang Kang, and two anonymous reviewers for their suggestions on the science and the written English of the manuscript.

\section{REFERENCES}

Allan RJ, Nicholls N, Jones PD and Butterworth IJ (1991) A further extension of the Tahiti-Darwin SOI, early ENSO events and Darwin pressure. J. Climate, 4(7), 743-749 (doi: 10.1175/15200442(1991)004<0743:AFEOTT>2.0.CO;2)

Braganza K, Gergis JL, Power SB, Risbey JS and Fowler AM (2009) A multiproxy index of the El Nino-Southern Oscillation, AD 1525-1982. J. Geophys. Res. Atmos. 114(D5), D05106 (doi: 10.1029/2008JD010896)

Cook ER, D'Arrigo RD and Anchukaitis KJ (2008) ENSO reconstructions from long tree-ring chronologies: unifying the differences? Presentation at special workshop at Moorea, French Polynesia, 2-3 April 2008 - Reconciling ENSO chronologies for the past 500 years. IGBP PAGES/World Data Center for Paleoclimatology, NOAA/NCDC Paleoclimatology Program, Boulder CO, USA

D'Arrigo R, Cook ER, Wilson RJ, Allan R and Mann ME (2005) On the variability of ENSO over the past six centuries. Geophys. Res. Lett., 32(3), L03711 (doi: 10.1029/2004GL022055)

Davis ME, Thompson LG, Yao T and Wang N (2005) Forcing of the Asian monsoon on the Tibetan Plateau: evidence from highresolution ice core and tropical coral records. J. Geophys. Res. Atmos., 110(D4), D04101 (doi: 10.1029/2004JD004933)

Fowler AM, Boswijk G, Gergis J and Lorrey A (2008) ENSO history recorded in Agathis australis (kauri) tree rings. Part A: kauri's potential as an ENSO proxy. Int. J. Climatol., 28(1), 1-20 (doi: 10.1002/joc.1525)

Grigholm B and 6 others (2009) Atmospheric soluble dust records from a Tibetan ice core: possible climate proxies and 
teleconnection with the Pacific Decadal Oscillation. J. Geophys. Res. Atmos., 114(D20), D20118, (doi: 10.1029/ 2008JD011242)

Grinsted A, Moore JC and Jevrejeva S (2004) Application of the cross wavelet transform and wavelet coherence to geophysical time series. Nonlinear Proc. Geophys., 11(5/6), 561-566 (doi: 10.5194/npg-11-561-2004)

Hou S and 7 others (2004) Age of Himalayan bottom ice cores. J. Glaciol., 50(170), 467-468 (doi: 10.3189/ $172756504781829981)$

Kang S and 7 others (2002) Glaciochemical records from a Mt. Everest ice core: relationship to atmospheric circulation over Asia. Atmos. Environ., 36(21), 3351-3361 (doi: 10.1016/S13522310(02)00325-4)

Kaspari S and 11 others (2007) Reduction in northward incursions of the South Asian monsoon since 1400 AD inferred from a Mt. Everest ice core. Geophys. Res. Lett., 34(16), L16701 (doi: 10.1029/2007GL030440)

Kaspari S, Hooke RLeB, Mayewski PA, Kang S, Hou S and Qin D (2008) Snow accumulation rate on Qomolangma (Mount Everest), Himalaya: synchroneity with sites across the Tibetan Plateau on 50-100 year timescales. J. Glaciol., 54(185), 343-352 (doi: 10.3189/002214308784886126)

Kaspari S and 7 others (2009) A high-resolution record of atmospheric dust composition and variability since AD 1650 from a Mount Everest ice core. J. Climate, 22(14), 3910-3925 (doi: 10.1175/2009JCLI2518.1)

Knüsel S, Brütsch S, Henderson KA, Palmer AS and Schwikowski M (2005) ENSO signals of the twentieth century in an ice core from Nevado Illimani, Bolivia. J. Geophys. Res. Atmos, 110(D1), D01102 (doi: 10.1029/2004JD005420)

Können GP, Jones PD, Kaltofen MH and Allan RJ (1998) Pre-1866 extensions of the Southern Oscillation index using early Indonesian and Tahitian meteorological readings. J. Climate., 11(9), 2325-2339 (doi: 10.1175/1520-00442(1998)011<2325: $\mathrm{PEOTSO}>2.0 . \mathrm{CO} ; 2)$

Li J and 8 others (2011) Interdecadal modulation of El Niño amplitude during the past millennium. Nature Climate Change, 1(2), 114-118 (doi: 10.1038/nclimate1086)

Li J and 11 others (2013) El Niño modulations over the past seven centuries. Nature Climate Change, 3(9), 822-826 (doi: 10.1038/ nclimate1936).

Mayewski PA, Ahmad N, Smith G and Pourchet M (1984) Interpretation of the chemical and physical time-series retrieved from Sentik Glacier, Ladakh Himalaya, India. J. Glaciol., 30(104), 66-76

McGregor S, Timmermann A and Timm O (2010) A unified proxy for ENSO and PDO variability since 1650. Climate Past., 6(1), 1-17 (doi: 10.5194/cp-6-1-2010)

Meeker LD and Mayewski PA (2002) A 1400-year highresolution record of atmospheric circulation over the North Atlantic and Asia. Holocene, 12(3), 257-266 (doi: 10.1191/ $0959683602 \mathrm{hl} 542 \mathrm{ft}$ )

Meeker LD, Mayewski PA and Bloomfield P (1995) A new approach to glaciochemical time series analysis. In Delmas RJ ed. Ice core studies of global biogeochemical cycles. (NATO ASI Series I: Global Environmental Change 30) Springer, Berlin, 383-400

Mokhov II and Smirnov DA (2006) El Niño-Southern Oscillation drives North Atlantic Oscillation as revealed with nonlinear techniques from climatic indices. Geophys. Res. Lett., 33(3) (doi: 10.1029/2005GL024557)

Osterberg EC, Handley MJ, Sneed SB, Mayewski PA and Kreutz KJ (2006) Continuous ice core melter system with discrete sampling for major ion, trace element and stable isotope analyses. Environ. Sci. Technol., 40(10), 3355-3361 (doi: 10.1021/ es052536w).

Ropelewski CF and Jones PD (1987) An extension of the TahitiDarwin southern oscillation index. Mon. Weather Rev., 115(9), 2161-2165 (doi: 10.1175/1520-0493(1987)115<2161: AEOTTS $>2.0 . C O ; 2)$

Shrestha AB, Wake CP, Dibb JE and Whitlow SI (2002) Aerosol and precipitation chemistry at a remote Himalayan site in Nepal. Aerosol Sci. Technol., 36(4), 441-456 (doi: 10.1080/ 027868202753571269)

Thompson LG, Yao T, Mosley-Thompson E, Davis ME, Henderson KA and Lin P (2000) A high-resolution millennial record of the south Asian monsoon from Himalayan ice cores. Science, 289(5486), 1916-1919 (doi: 10.1126/science.289. 5486.1916)

Wake CP, Mayewski PA and Spencer MJ (1990) A review of central Asian glaciochemical data. Ann. Glaciol., 14, 301-306

Wake CP, Mayewski PA, Xie Z, Wang P and Li Z (1993) Regional distribution of monsoon and desert dust signals recorded in Asian glaciers. Geophys. Res. Lett., 20(14), 1411-1414 (doi: 10.1029/93GL01682)

Wang N, Yao T, Thompson LG and Davis ME (2002) Indian monsoon and North Atlantic Oscillation signals reflected by $\mathrm{Cl}^{-}$ and $\mathrm{Na}^{+}$in a shallow ice core from Dasuopu glacier, Xixabangma, Himalaya. Ann. Glaciol., 35(1), 273-277 (doi: 10.3189/172756402781816825)

Wang N, Thompson LG, Davis ME, Mosley-Thompson E, Yao T and $\mathrm{Pu} J$ (2003) Influence of variations in NAO and SO on air temperature over the northern Tibetan Plateau as recorded by $\delta^{18} \mathrm{O}$ in the Malan ice core. Geophys. Res. Lett., 30(22), 2167 (doi: 10.1029/2003GL018188)

Xu H, Hou S and Pang H (2014) Asian-Pacific Oscillation signal from a Qomolangma (Mount Everest) ice-core chemical record. Ann. Glaciol., 55(66), 121-128 (doi: 10.3189/ 2014AoG66A121)

$\mathrm{Xu} \mathrm{J}$ and 10 others (2010) A $108.83 \mathrm{~m}$ ice-core record of atmospheric dust deposition at Mt. Qomolangma (Everest), Central Himalaya. Quat. Res., 73(1), 33-38 (doi: 0.1016/j.yqres. 2009.09.005)

Yang M, Yao T, He Y and Thompson L G (2000) ENSO events recorded in the Guliya ice core. Climatic Change, 47(4), 401-409 (doi: 10.1023/A:1005696702385)

Zhang XP, Yao TD and Jin HJ (2000) The influence of ENSO event on the modern $\delta^{18} \mathrm{O}$ on the Guliya ice core. J. Glaciol. Geocryol., 22(1), 24-28 